\title{
The Impact of Coal and Biomass Co-Firing on the Economy of Power Plant Carbon Capture
}

\author{
Quan Zhuang*, Philip Geddis, Bruce Clements \\ Natural Resources Canada, CanmetENERGY-Ottawa, 1 Haanel Drive, Ottawa, ON K1A 1M1, Canada \\ Email: quan.zhuang@canada.ca
}

Received: 9 November 2020; Accepted: 30 November 2020; Available online: 20 December 2020

\begin{abstract}
A detailed economic evaluation was carried out to determine the impact of biomass and coal co-firing on power plant carbon capture by methods of plants equipment designing factors and performance, and the sum up of the associated breakdowns of CAPEX and OPEX. Based on the assumptions of the $\mathrm{CO}_{2}$ neutrality of biomass and likely governmental incentives to reduce $\mathrm{CO}_{2}$ emissions, the study results show that biomass and coal cofiring would result in both lower cost of carbon avoided (carbon capture) and lower incremental cost of electricity generation when MEA solvent carbon capture is applied. Two scenarios for co-firing with carbon capture, $30 \%$ biomass blending and $90 \%$ or $60 \% \mathrm{CO}_{2}$ capture from stack, indicate different preference depending on lower or higher incentives.
\end{abstract}

Keywords: Coal and biomass co-firing; Carbon capture; Renewable energy; Economic evaluation; $\mathrm{Cost}_{\text {of }} \mathrm{CO}_{2}$ avoided.

\section{Introduction}

After decades of investigation, mitigating climate changing is regarded as a worldwide priority [1,2]. For stationary emission sources of carbon dioxide $\left(\mathrm{CO}_{2}\right)$, several efforts are being pursued, in which exploration of renewable energy utilization and carbon capture stand out as the most probable strategies to achieve the long term goal of worldwide sustainable development [3-6].

Biomass is a widely available renewable energy resource. Plants undergo a natural growth and decay cycle. Carbon dioxide $\left(\mathrm{CO}_{2}\right)$ in the atmosphere is fixed into the body of biomass in the growth period, and then released back to the atmosphere while decaying. When sustainable biomass is harvested and consumed as an energy resource, the fixed carbon in the biomass body is converted back to $\mathrm{CO}_{2}$ and released to the atmosphere, without incurring a net increase in the atmosphere [7]. Therefore, biomass is regarded as a carbon neutral energy resource. There are potential ways to utilize biomass, however, some require the development of new combustion technologies [6,8]. A simple and economic way is to adopt coal and biomass co-firing in existing power plants, which has been practiced for decades, as it can be technologically viable for existing power plants [6]. It is anticipated that more and more power plants will adopt the co-firing strategy in the near future. As for carbon mitigation strategies, post combustion capture is the most probable strategy compared to integrated gasification combined cycle (IGCC) and oxy-fuel combustion in terms of technology readiness [9,10]. If a post combustion carbon capture technology is applied to a biomass (or partial biomass) fired boiler, a scenario of negative carbon emission could be created, i.e., the $\mathrm{CO}_{2}$ is removed out of the atmosphere into the ground via biomass harvest, combustion, carbon capture and sequestration. This could be the most preferable scenario in limiting global warming $[1,3,11]$.

Carbon tax and trading schemes have been proposed for years and now they are being practiced in Europe and some North American jurisdictions [12,16]. This is to provide an economic penalty for status-quo, and also a financial incentive to encourage using more renewable energy or carbon capture technologies. The Government of Canada recently introduced a Pan-Canadian Framework on Clean Growth and Climate Change that will allow individual provinces to select their own pricing system, with minimum requirements for incremental carbon price increases over time (rising from a minimum of CAD \$10/tonne in 2018 to CAD\$50/tonne in 2022) [17].

Although it is planned to phase out coal power generation down the road, there are still 26 coal-fired power plants in operation in Canada as of 2020, will remain more or less steady until 2030 [18]. On the other hand, shalegas production in the United States is reaching peak now or in the first half of 2020s [19]. Worldwide, coal reserves will last for hundreds of years, whereas, natural gas will only last for decades [20]. How coal-fired power generations will be evolving remains to be seen. As recent publications on coal and biomass co-firing show continuing activities, it is still necessary for studies like this to continue. 
In this paper, a detailed economic evaluation of carbon capture for coal and biomass co-firing in a power plant is presented. The impact of co-firing on power plant de-rating, carbon capture equipment sizing, and the related cost increase are investigated. The level of carbon incentive is a major factor affecting the carbon capture cost as well as the resultant incremental cost of electricity generation. The results show that, under several scenarios, by co-firing biomass with coal, both carbon capture and incremental costs of power generation could be lowered. This study is intended to provide some economic impacts of biomass-coal co-firing to the Canadian power industry for considering and planning to adopt technologies of biomass utilization and carbon capture with existing boilers when $\mathrm{CO}_{2}$ emission regulations come into play in the near future.

\section{Methodology}

A common approach for the economic evaluation of post combustion carbon capture has been applied in this study [21-23]. Most of the coal fired power plants in Canada were designed and constructed over 30 years ago. A typical Canadian $150 \mathrm{MW}_{\mathrm{e}}$ subcritical boiler tangentially firing high volatile Colombian bituminous coal was chosen as a base case (reference case).

A $30 \mathrm{wt} \%$ monoethanolamine (MEA) solution was chosen as the $\mathrm{CO}_{2}$ capture solvent. A process flow diagram of an existing power plant with an add-on carbon capture plant is illustrated in Fig. 1. A post combustion carbon capture process is shown in Fig. 2.

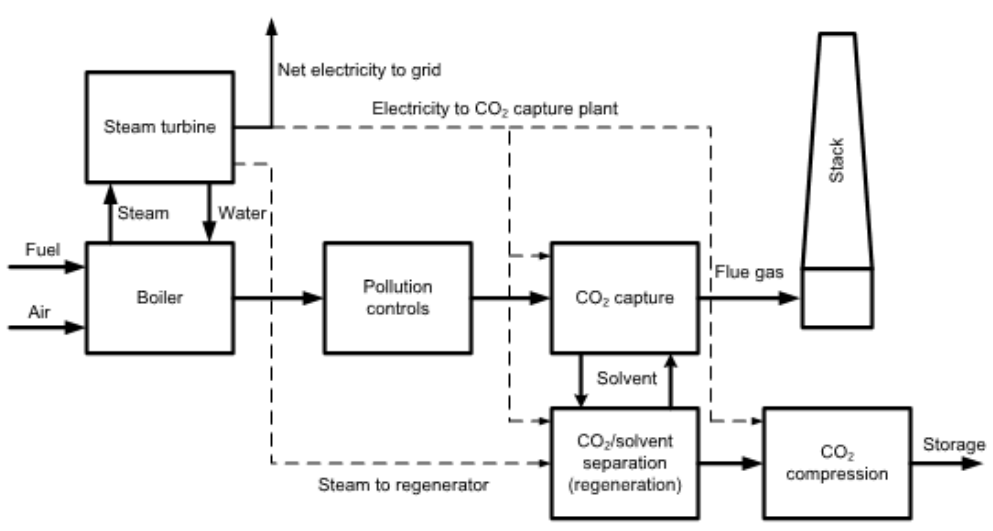

Figure 1. A typical power plant with an added $\mathrm{CO}_{2}$ capture process

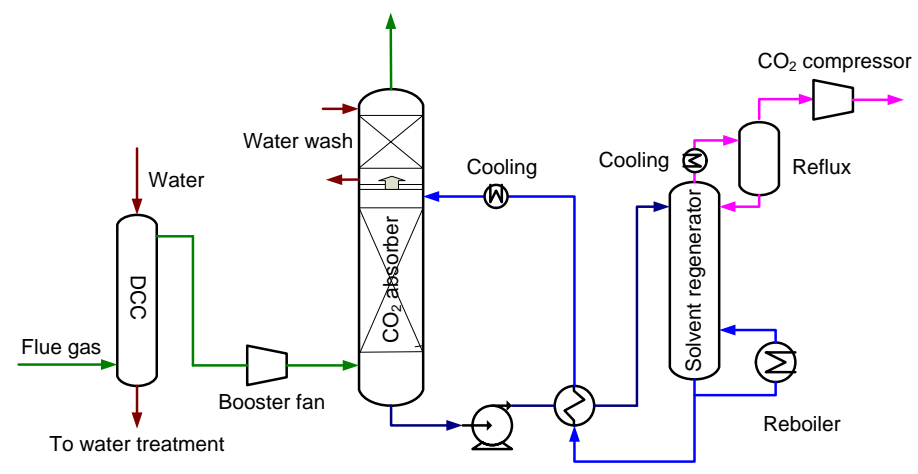

Figure 2. Post combustion $\mathrm{CO}_{2}$ capture process (DCC: direct contact cooling)

The electricity and steam needed for the carbon capture process are extracted from the existing power plant as shown with the dashed lines in Fig. 1. Thus the power plant will experience a de-rating [24]. The performance influence of extracting steam for the post combustion capture (PCC) re-boiler from the low pressure (LP) turbine is assumed nil other than de-rating.

Three cases were evaluated;

1) Baseline case: coal fired case achieving $90 \%$ capture of $\mathrm{CO}_{2}$ through PCC

2) Case 1: co-firing 30\% biomass (by heat input) to achieve $90 \% \mathrm{CO}_{2}$ capture by PCC

3) Case 2: co-firing $30 \%$ biomass (by heat input) to achieve $60 \% \mathrm{CO}_{2}$ capture by PCC 
The baseline case is a coal fired operation with $90 \% \mathrm{CO}_{2}$ capture. It is assumed that a future regulation would require $90 \% \mathrm{CO}_{2}$ capture for coal fired power plants, because capturing the last $10 \%$ of $\mathrm{CO}_{2}$ is not cost effective.

The Colombian bituminous coal (which is being fired in a Canadian 150 MWe power plant) and biomass (a Canadian commercial wood chip) analyses are shown in Table 1. The moisture of the air-dried Canadian wood chips is in the range of reported values $[25,26]$. The flue gas compositions of the coal case and the co-firing case are summarized in Table 2, derived by combustion calculation from the fuels. The influence of the co-firing ratio on $\mathrm{CO}_{2}$ emissions is shown in Table 3. Biomass is considered carbon neutral and therefore the reduction of $\mathrm{CO}_{2}$ emission in the co-firing case is the same as the co-firing ratio, i.e., $30 \%$ co-firing is equivalent to a $30 \% \mathrm{CO}_{2}$ emission reduction. In Table 3, the real $\mathrm{CO}_{2}$ emission (from coal or biomass or both of them) amounts are the sum of the $\mathrm{CO}_{2}$ generated from both coal and biomass. At the moment, the biomass co-firing ratio is typically from 3 to $15 \%[1,27]$. A higher co-firing ratio in the future is anticipated, and has already been demonstrated in a fullscale power plant [26]. It can be seen from Table 3 that when co-firing $30 \%$ biomass with coal, the total fuel feeding volume would be more than doubled. This is one of the restrictions for biomass co-firing at higher ratios in existing power plants; the existing coal feeding system would not be able to handle such high volumetric throughput. Other restrictions may relate to slagging, fouling, corrosion, ash control.

Table 1. Fuel analyses

\begin{tabular}{lcc}
\hline & Colombian coal & Canadian wood chips \\
\hline Proximate analysis & As received (wt\%) & As received (wt\%) \\
Moisture & 10.7 & 13.0 \\
Ash & 9.6 & 0.58 \\
Volatile matter & 32.5 & 72.16 \\
Fixed carbon & 47.1 & 14.26 \\
Total & 100.0 & 100 \\
\hline Ultimate analysis (dry ash free) & & \\
C & 81.09 & 50.16 \\
H & 5.47 & 6.16 \\
N & 1.67 & 0.13 \\
S & 1.26 & 0.05 \\
O & 10.52 & 43.51 \\
Total & 100.00 & 100.00 \\
\hline Heating value (BTU/lb) & 12430 & 8125 \\
(kJ/kg) & 29154 & 19057 \\
\hline
\end{tabular}

Table 2. Flue gas compositions in mole\% and the total flue gas amounts

\begin{tabular}{ccc}
\hline Gaseous component & Coal only & Coal and 30\% biomass co-firing \\
\hline $\mathrm{N}_{2}$ & 74.62 & 73.15 \\
$\mathrm{CO}_{2}$ & 14.73 & 14.82 \\
$\mathrm{H}_{2} \mathrm{O}$ & 7.48 & 8.89 \\
$\mathrm{O}_{2}$ & 2.97 & 2.97 \\
$\mathrm{NO}$ & 0.01 & 0.01 \\
$\mathrm{SO}_{2}$ & 0.03 & 0.03 \\
$\mathrm{CO}$ & 0.00 & 0.00 \\
Total & 100 & 100 \\
Fuel amount $\left(\mathrm{t} / \mathrm{h}^{\mathrm{b}}\right)$ & 56.65 & 65.65 \\
Air amount required $(\mathrm{t} / \mathrm{h})$ & 626.52 & 618.29 \\
Flue gas amount $(\mathrm{t} / \mathrm{h})$ & 683.14 & 683.94 \\
\hline
\end{tabular}

a: by higher heating value; b: metric tonne

Table 3. Co-firing performance with various biomass ratios

\begin{tabular}{lllllll}
\hline Co-firing ratio (HHV\%) & 5 & 10 & 15 & 20 & 25 & 30 \\
\hline Biomass ratio (wt\%) & 7.45 & 14.53 & 21.26 & 27.26 & 33.77 & 39.6 \\
Additional mass input (wt\%) & 2.65 & 5.3 & 7.95 & 10.6 & 13.25 & 15.9 \\
Fuel volume increase (\%) & 22.47 & 44.36 & 66.26 & 88.16 & 110.06 & 113.95 \\
Reduction in $\mathrm{CO}_{2}$ emission (\%) & 5 & 10 & 15 & 20 & 25 & 30 \\
${\text { Real } \mathrm{CO}_{2} \text { emission (\%) }}^{\mathrm{b}}$ & 100.12 & 100.24 & 100.36 & 100.48 & 100.61 & 100.73 \\
\hline
\end{tabular}

a: reduction in fossil fuel $\mathrm{CO}_{2}$ emission

b: fossil fuel $\mathrm{CO}_{2}$ plus biogenic $\mathrm{CO}_{2}$ 
In Europe, it is being practiced under the Green Certificate or ETS Mechanism that governmental incentives or subsidies are given to power plant for biomass firing and adoption of lower carbon emission measures [5,6,28]. At some point in the future, other judiciaries may follow suit. The evaluated case matrix is shown in Table 4 . In Case $1,90 \%$ of the total $\mathrm{CO}_{2}$ is to be captured, in which $30 \%$ is from biomass. This means that $30 \% \mathrm{more}^{\mathrm{CO}_{2}}$ is captured than required by the assumed future regulation. For this part, the power plant would get credit (30\% negative emission). The $60 \%$ capture in Case 2 is equivalent to the $90 \%$ capture in the Base Case. There would be no carbon credit.

FLUOR Corporation has conducted a detailed study of engineering design of an amine $\mathrm{CO}_{2}$ capture plant for existing Canadian power plants [29]. Some of the items in the present study are referenced to the results of the FLUOR report.

Table 4. Cases evaluated in the study

\begin{tabular}{llll}
\hline & Base Case & Case 1 & Case 2 \\
\hline Fuel & $100 \%$ Bituminous coal & $70 \%$ Bituminous coal and & $70 \%$ Bituminous coal and 30\% wood \\
& & $30 \%$ wood chips & chips \\
$\mathrm{CO}_{2}$ Capture Rate & $90 \%$ & $90 \%$ & $60 \%$ \\
\hline
\end{tabular}

\subsection{General assumptions and conditions}

The following conditions were used in the evaluation. The power plant energy efficiency was based on fuel (coal and biomass) higher heating values. The sensitivity to $\mathrm{CO}_{2}$ price was also evaluated.

Boiler:

Base Plant Capacity:

Coal:

Biomass price:

Capacity Factor:

$\mathrm{CO}_{2}$ capture solvent:

$\mathrm{CO}_{2}$ Capture Efficiency:

$\mathrm{CO}_{2}$ incentive:

Construction period:

Carbon capture plant life:

Interest rate:

Cost reported in:
Subcritical tangentially fired

$150 \mathrm{MW}_{\mathrm{e}}$ (net before retrofitting to capture carbon)

low sulphur high volatile Colombian bituminous

the same as coal (an assumption)

$85 \%$

$30 \mathrm{wt} \%$ MEA aqueous solution

$90 \%$ (as required by future regulation)

$\$ 50 /$ tonne (\$0 - 80/tonne)

3 years

30 years

$10 \%$

Constant 2017 U.S. Dollars ${ }^{[30,31]}$

\section{$2.2 \mathrm{CO}_{2}$ capture and regeneration process description}

From the flue gas quantity and conditions, the sizes of the $\mathrm{CO}_{2}$ absorber, rich solvent regenerator, blowers, pumps, and other minor items, were determined. The costs of the equipment and components were derived by engineering and economic evaluations based on available published sources as well as by contacting commercial equipment providers [21,22]. The equipment design/operation conditions are as follows, which were referenced to a detailed design report [29], based on a real Canadian power plant in operation.

\section{1) Flue Gas Pre-Cooling}

The flue gas exits the power plant particulate matter (PM) control device at $147^{\circ} \mathrm{C}$. For better absorption, the flue gas is cooled to $44^{\circ} \mathrm{C}$ by a direct contact cooler. The cooling water temperature is $23^{\circ} \mathrm{C}$.

\section{2) Flue Gas Booster Blower}

A flue gas booster blower is positioned between the quench cooler and the absorber. The flue gas leaves the blowers at $44^{\circ} \mathrm{C}$ and a gauge pressure of $5.6 \mathrm{kPa}$.

\section{3) Absorber}

In the absorber tower, the aqueous amine solution is sprayed downward. The flue gas enters from the bottom of the absorber. A small amount of ammonia evolves from MEA degradation; a wash section at the top of the absorber above the packed bed section washes away the ammonia to below 50 ppmv. The ammonia rich water then trickles down a tube which is fed back into the absorber at the top of the packed bed section. The packing is CMR 3, a commercial product [29].

\section{4) Solvent Cross Heat Exchanger}

The aqueous amine solution falls down into the bottom of the absorber tower after it is reacted with the carbon dioxide in the flue gas. The solution then is pumped to a rich/lean solvent heat exchanger. Heat taken from the lean solvent stream is used to heat up the rich solvent stream in the heat exchanger. The type of heat exchanger for this process is a fixed shell and tube heat exchanger. The rich solvent enters the shell side at $42.8^{\circ} \mathrm{C}$ and $550 \mathrm{kPa}$ gauge pressure, and leaves at $112^{\circ} \mathrm{C}$. The lean stream enters the tube side at $121^{\circ} \mathrm{C}$ and $82 \mathrm{kPa}$ gauge pressure and leaves at $52.8^{\circ} \mathrm{C}$. Next, the lean solvent stream should go through a further cooling step. 


\section{5) Lean Solvent Cooling Unit}

The absorber requires the lean solvent to be fed at a temperature of $38^{\circ} \mathrm{C}$. Therefore, a cooling step is required meeting the absorber inlet condition. The type of cooling unit for this step is a fixed tube and shell heat exchanger. The solvent is cooled down by cooling water with inlet and outlet temperatures of $24^{\circ} \mathrm{C}$ and $49^{\circ} \mathrm{C}$, respectively.

6) Regenerator

In this unit operation, the rich solvent is regenerated. The condition is $120^{\circ} \mathrm{C}$ and $345 \mathrm{kPa}$. In order to minimize the energy consumption, the loading ratio of carbon dioxide over solvent must be high. In the Base Case and Case 1 , the weight ratio of carbon dioxide over solvent is set to be 1:5, whereas the ratio of Case 2 is $1: 2.5$. According to a kinetics study, with $60 \%$ capture the $\mathrm{CO}_{2}$ loading capacity would be tripled [21]. Therefore, much less solvent would be required, meaning a more efficient carbon capture.

\subsection{Process description of the product recovery train (PRT) \\ 1) Reflux Drum and Product Recovery Train}

The $\mathrm{CO}_{2}$ and water vapour mixture is sent to the reflux drum in the post-generation stage. The objective is to eliminate the suspended water droplets from the carbon dioxide gas stream by providing residence time in order to allow the droplets to precipitate. The water condensed in this step is sent back to the wash cycle in the absorber. The reflux drum is a two-phase vertical vessel. Once the vapour exits the reflux drum, it contains approximate 99.7\% $\mathrm{CO}_{2}$, and is sent to the product recovery train where it is compressed and sent off for transportation by pipeline or truck and sequestration at a geologic site. The $\mathrm{CO}_{2}$ is delivered at $10 \mathrm{MPa}$ and $30^{\circ} \mathrm{C}$ [32].

\section{2) $\mathrm{CO}_{2}$ Gas Cooling Unit}

The $\mathrm{CO}_{2}$ mixture (99.7\%) leaves the regenerator at a temperature of $120^{\circ} \mathrm{C}$ and a pressure of $345 \mathrm{kPa}$. The mixture must be cooled down to about $32^{\circ} \mathrm{C}$ in order to condense the last portion of water in the mixture, and this will result in $99.9 \%$ purity of $\mathrm{CO}_{2}$. The type of unit selected for this process is a fixed-tube and shell heat exchanger. The mixture enters the heat exchanger at $120^{\circ} \mathrm{C}$. It is cooled down by counter-current flow cooling water whose inlet and outlet temperature are $23^{\circ} \mathrm{C}$ and $48.9^{\circ} \mathrm{C}$, respectively.

3) $\mathrm{CO}_{2}$ Gas Compression (stage 1 and 2)

The $\mathrm{CO}_{2}\left(99.9 \% \mathrm{CO}_{2}\right)$ leaves the $\mathrm{CO}_{2}$ gas a cooling unit at a temperature of $30^{\circ} \mathrm{C}$. It is crucial to compress the $\mathrm{CO}_{2}$ stream to $10 \mathrm{MPa}$ to supercritical state for transportation. The compressor can handle inlet temperature ranging from $5^{\circ} \mathrm{C}$ to $130^{\circ} \mathrm{C}$, and has a compression ratio of 9:1. For this purpose, the developed compressor can insert cooling function to cool down the $\mathrm{CO}_{2}$ stream while compressing it [29,33]. The most economic delivery conditions for sequestration of $\mathrm{CO}_{2}$ are determined to be about $10 \mathrm{MPa}$ and $30^{\circ} \mathrm{C}$ [34]. If the $\mathrm{CO}_{2}$ is compressed in one stage from 1.5 bar to $10 \mathrm{MPa}$, the temperature of the stream would reach about $300^{\circ} \mathrm{C}$. This is far beyond the operating conditions most of the compressors can handle. Therefore, it is essential to use ad least two stages of compression. The $\mathrm{CO}_{2}$ enters the first stage of compression at $32^{\circ} \mathrm{C}$ and $327 \mathrm{kPa}$, where it is compressed to a pressure of $1.33 \mathrm{MPa}$ and a temperature of $130^{\circ} \mathrm{C}$ with internal cooling. The compression ratio for the first stage is 9:1. It then enters a tube and shell heat exchanger where it is cooled by water to a temperature of $40^{\circ} \mathrm{C}$ and a pressure of $1130 \mathrm{kPa}$, assuming that the pressure drop of the $\mathrm{CO}_{2}$ stream is $200 \mathrm{kPa}$. The stream then goes through the second stage of compression. It is compressed to a pressure of $10 \mathrm{MPa}$ and a temperature of $130^{\circ} \mathrm{C}$ with internal cooling. The compression ratio for the second stage is 9:1. The $\mathrm{CO}_{2}$ then enters another tube and shell heat exchanger where it is chilled by cooling water to the delivery temperature of $30^{\circ} \mathrm{C}$ and a pressure of $10 \mathrm{MPa}$.

\section{4) Cooling Tower}

In order to increase the efficiency of the PRT (product recovery train), it is essential to recycle the cooling water to be reused for the heat exchanger. A wet cooling tower is appropriate for cooling the water. The water goes through the cooling tower at the temperature of $42^{\circ} \mathrm{C}$, and the temperature of the cooling tower outlet is $23^{\circ} \mathrm{C}$. The heat released in the cooling tower can be calculated according to the specific heat capacity of water, mass flow rate of cooling water, and the temperature change between the inlet and outlet of cooling tower. The transferred heat can be converted to tonne of air condition, and the cost of the cooling tower is then determined using the commercial handbook of costing according to the tonne of air condition [35].

\subsection{Cost indices and currency conversion}

Fluctuations in economic conditions cause price changes of purchased equipment, labour, and financial costs. Cost indices should be utilized to update old cost data in order to account for these changes. The conversion formula is:

$$
\text { Present Cost }=\text { Past Cost } x \text { (present Index Value / Past Index Values) }
$$

Two of the most common indices are the Marshall and Swift indices and Chemical Engineering Plant Cost Index (CEPCI). These two indices are recommended for plants costing, and they give very similar results. In this report, the CEPCI is used [22]. If a cost of a reference item was not available in US\$, it was converted to the US\$ by 
currency exchange rate of the year. The resultant US\$ costs are then transformed to the present value according to the index conversion mentioned above.

\subsection{Estimation of equipment costs by scaling} [22]:

When the cost of a piece of equipment of a particular size is not available, the six-tenth factor rule was used

$$
\text { Cost } 2=\text { Cost } 1 \times \text { (Capacity 2/Capacity } 1)^{0.6}
$$

\subsection{Nature of economic data}

The $\mathrm{CO}_{2}$ capture cost is composed of the items of fuel properties and cost, plant/equipment sizes, efficiency factor, financing, performance and maintenance of the $\mathrm{CO}_{2}$ capture system, and other environmental control systems.

The total capital cost of a plant consists of direct and indirect costs. The direct costs consist of: purchased equipment; equipment installation; instrumentation and controls; piping; electrical systems; buildings; yard improvements; service facilities; land.

Indirect costs include: engineering and supervision; construction expense; legal expenses; contractor's fees; contingencies.

\subsection{Costing method for capital}

From the flue gas quantity and conditions, the sizes of the $\mathrm{CO}_{2}$ absorber, rich solvent regenerator, fans, pumps, and other auxiliary equipment were determined.

The method is first to calculate the cost of all delivered equipment which marked as item ' $\mathrm{C}$ ' in Table 5. Then, every direct and indirect cost is calculated based on the item ' $\mathrm{C}$ '. The only item for next step calculation is the Total Fixed Capital Investment (FCI). FCI is not only one of the four root cost components of cost of electricity in the report, but also the important input for the cost of the Annual Operation and Maintenance which will be discussed in the next subsection.

Table 5. Fixed Capital Investment Estimation Method [22]

\begin{tabular}{ccc}
\hline & \multicolumn{1}{c}{ Component } & User Value \\
\hline A & Direct Costs & \\
B & Purchased Equipment & Sum of all equipments \\
C & Delivery, Percent of Purchased Equipment & $10 \%$ A \\
D & Subtotal: Delivered Equipment & A+B \\
E & Purchased Equipment Installation & $47 \%$ C \\
F & Instrumentation and Controls (Installed) & $36 \%$ C \\
G & Piping (Installed) & $68 \%$ C \\
H & Electrical Systems (Installed) & $11 \% \mathrm{C}$ \\
I & Buildings (Including Services) & $18 \% \mathrm{C}$ \\
J & Yard Improvements & $10 \% \mathrm{C}$ \\
K & Service Facilities (Installed) & $70 \% \mathrm{C}$ \\
L & Total Direct Cost & $\mathrm{C}+\mathrm{D}+\mathrm{E}+\mathrm{F}+\mathrm{G}+\mathrm{H}+\mathrm{I}+\mathrm{J}$ \\
$\mathrm{M}$ & Indirect Costs & $33 \% \mathrm{C}$ \\
$\mathrm{N}$ & Engineering and Supervision & $41 \% \mathrm{C}$ \\
$\mathrm{O}$ & Construction Expenses & $4 \% \mathrm{C}$ \\
$\mathrm{P}$ & Legal Expenses & $22 \% \mathrm{C}$ \\
$\mathrm{Q}$ & Contractor's Fee & $44 \% \mathrm{C}$ \\
$\mathrm{R}$ & Contingency & $\mathrm{M}+\mathrm{N}+\mathrm{O}+\mathrm{P}+\mathrm{Q}$ \\
\hline $\mathrm{S}$ & Total Indirect Cost & $\mathrm{K}+\mathrm{R}$ \\
$\mathrm{T}$ & Total Fixed-Capital Investment (FCI) & $89 \% \mathrm{C}$ \\
& Working Capital & $\mathrm{S}+\mathrm{T}$ \\
\hline
\end{tabular}

\subsection{Costing method for operating and maintenance}

The Annual Operating and Maintenance cost is calculated as a percentage of the FCI, Cost for Material, and Cost for Labour tabulated in Table 6. An iteration process is necessary for the final column of Table 6. 
Table 6. Annual Operating and Maintenance Cost [22]

\begin{tabular}{|c|c|c|}
\hline Item & Factor & Basis \\
\hline \multicolumn{3}{|l|}{ Variable Cost } \\
\hline Material & - & - \\
\hline Operating Labour (OL) & - & - \\
\hline Operating Supervision (OS) & 0.15 & OL \\
\hline Utilities & - & - \\
\hline Maintenance and Repairs (M\&R) & 0.06 & FCI \\
\hline Operating Supplies & 0.15 & $\mathrm{M} \& \mathrm{R}$ \\
\hline Laboratory Charges & 0.15 & $\mathrm{OL}$ \\
\hline \multicolumn{3}{|l|}{ Total Variable Costs (TVC) } \\
\hline \multicolumn{3}{|l|}{ Fixed Charges } \\
\hline Property Taxes & 0.02 & FCI \\
\hline Interest Financing & 0.10 & FCI \\
\hline Insurance & 0.01 & FCI \\
\hline \multicolumn{3}{|l|}{ Total Fixed Charges (TFC) } \\
\hline \multicolumn{3}{|l|}{ Plant Overhead } \\
\hline Safety and Protection & 0.05 & OL,OS,M\&R \\
\hline General & 0.60 & OL,OS,M\&R \\
\hline \multicolumn{3}{|l|}{ Total Plant Overhead (TPO) } \\
\hline \multicolumn{3}{|l|}{ General Expenses } \\
\hline Administration & 0.20 & OL,OS,M\&R \\
\hline Distribution & 0.05 & O\&M \\
\hline Research and Development & 0.04 & $\mathrm{O} \& \mathrm{M}$ \\
\hline Total General Expenses (TGE) & & \\
\hline Annual Operating and Maintenance & TV & C+TPO+TGE \\
\hline
\end{tabular}

\subsection{Costs for materials}

The cost of the absorbent is determined by the cost of amine stated on the Chemical Market Reporter [36], and the mass flow rate of amine which compensates for the amine losses due to degradation and evaporation in the system, i.e., the makeup amine.

\subsection{Costs for labor}

The correlation used to determine the annual cost for labor simply relates to the skilled wage, the employee hours per day, and the days of operation. The employee hours per day is based on the assumption that there are 9 operators working a combined 72 hours in a day.

Cost for labour = 72 (hr/day) x 310.25 (day/yr) x 33.67 (2002) USD/hr) x 1.57 (2017 USD)/(2012 USD)

\subsection{Cost formula of $\mathrm{CO}_{2}$ avoided}

(Annualized Cost $\mathrm{w}_{\mathrm{CO}} \mathrm{CO}_{2}$ Capture - Annualized Cost $\mathrm{w} / \mathrm{o} \mathrm{CO} \mathrm{CO}_{2}$ Capture) / $150 \mathrm{MW}$

Total Tonnes of $\mathrm{CO}_{2}$ Captured /150MW

Cost of Power Plant Derating =

Plant Net Power (w/o $\mathrm{CO}_{2}$ Capture)*Plant Derating Rate*Price of Electricity (w $\mathrm{CO}_{2}$ Avoided),

Plant Derating Rate $=$ Power requirement of pumps and fans $/ 150 M W+$ Reboiler heat duty $/$ Plant heat requirement,

and

Annualized Plant Cost per Tonne $\mathrm{CO}_{2}$ Captured $=\left(\right.$ Annualized Plant Cost for $\mathrm{CO}_{2}$ Capture only) $/($ Total Tonnes of $\mathrm{CO}_{2}$ Captured),

and

Electricity Generation Increment per Tonne $\mathrm{CO}_{2}$ Captured $=$ Capital + O\&M + Purchase Cost for Derating Power - $\mathrm{CO}_{2}$ Credit / (Total Tonnes of $\mathrm{CO}_{2}$ Captured), 


\section{Findings and discussions}

The major capital costs of the evaluated three cases are shown in Table 7. It can be seen from Table 2 that both the flue gas quantities and composition of the coal fired and the 30\% biomass coal co-fired cases are very close. Therefore, the capital costs of the Base Case and Case 1 are almost the same, whereas for Case 2, only 60\% of the $\mathrm{CO}_{2}$ in the flue gas needs to be captured. This results in size reduction of the equipment of the $\mathrm{CO}_{2}$ capture plant. Therefore, the capital costs of the equipment of the carbon capture plant are lower. In this study, the regenerator and product recovery train are listed separately, whereas, other studies may report them as a "regeneration unit" [37].

Table 7. Major capital costs of $\mathrm{CO}_{2}$ capture equipment

\begin{tabular}{llll}
\hline Purchase cost (US\$) & Base case & Case 1 & Case 2 \\
\hline Cooling towers / heat exchangers & $3,999,563$ & $3,999,563$ & $2,738,283$ \\
Absorber & $7,589,518$ & $7,589,518$ & $5,649,049$ \\
Regenerator & $2,098,408$ & $2,098,408$ & $1,316,644$ \\
Product recover train & $9,407,291$ & $9,407,291$ & $4,968,788$ \\
\hline
\end{tabular}

The major energy consuming operations of the $\mathrm{CO}_{2}$ capture plants for the three cases are shown in Table 8. For the Base Case and Case 1, the same amount of flue gas is processed and the same percentage of $\mathrm{CO}_{2}$ is to be captured (in Case $1, \mathrm{CO}_{2}$ from biomass is also captured). Thus the energy consumptions by the $\mathrm{CO}_{2}$ capture plants are the same. Less $\mathrm{CO}_{2}$ is to be captured in Case 2, therefore less energy is consumed by the $\mathrm{CO}_{2}$ capture plant.

Table 8. Energy consumption by the carbon capture plant (MW)

\begin{tabular}{cccc}
\hline & Base case & Case 1 & Case 2 \\
\hline Regeneration steam & 68.9 & 68.9 & 45.9 \\
Compression & 11.2 & 11.2 & 7.6 \\
Fan / pump & 3.8 & 3.8 & 3 \\
\hline
\end{tabular}

The electricity and steam required by the $\mathrm{CO}_{2}$ capture plant are extracted from the power plant. This would result in de-rating for the power plant. As shown in Figure 3, the Base Case and Case 1 have the same de-rating. The de-rating of Case 2 is lower because, capturing less $\mathrm{CO}_{2}$ consumes less energy (i.e., less electricity and steam). De-rating results of studies by others (the year of the studies are shown in brackets) are also plotted in Figure 3 for comparison [21].

The costs of the $\mathrm{CO}_{2}$ avoided and the electricity generation increment of both the co-firing cases are lower than the Base Case (Fig. 4). For Case 1, the cost reduction is due to the $\mathrm{CO}_{2}$ credit, i.e., capturing $90 \%$ is equivalent to capturing 120\% (negative emission). The power plant in Case 1 gets credits for capturing 30\% more $\mathrm{CO}_{2}$ than required by the regulation (one of the assumptions in this study). For Case 2, $60 \% \mathrm{CO}_{2}$ capture is equivalent to $90 \%$ capture of the Base Case required by the regulation. So, the power plant in Case 2 would not get any credit. Its cost reduction of $\mathrm{CO}_{2}$ avoided and electricity generation increment is due to the smaller size of the equipment and the related lower capital, O\&M costs and lower de-rating.

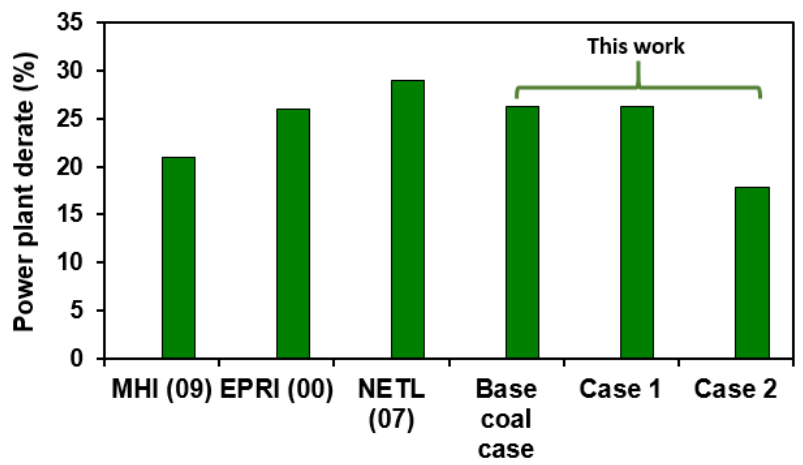

Figure 3. Derating by installing $\mathrm{CO}_{2}$ capture plant (the number is the year the report was published [21])

At the moment, the trading price of $\mathrm{CO}_{2}$ in Europe and California is in a range of US\$10 - 30 per tonne [38]. The Canadian federal carbon tax is set to start at C $\$ 10 /$ tonne sometime in 2018. As of early 2018, the province of Alberta already charges carbon tax for $\mathrm{C} \$ 30$ a tonne [39]. A study predicted a $\mathrm{CO}_{2}$ price of $\$ 70$ in 2030 and $\$ 180$ 
in 2050 [17,40]. The influence of the $\mathrm{CO}_{2}$ incentive on the power plant performance with biomass co-firing and $\mathrm{CO}_{2}$ capture is depicted in Figure 5. As discussed above, the $\mathrm{CO}_{2}$ incentive would only impact on Case 1, but not Case 2. At lower $\mathrm{CO}_{2}$ incentive values, Case 2 is preferable. At higher $\mathrm{CO}_{2}$ incentive values, Case 1 performs better.

To compare our study results with others, the dollar numbers look higher (Figure 4) [37,41,42]. This is because

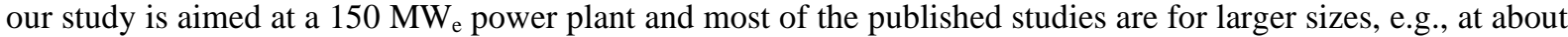
$500 \mathrm{MW}_{\mathrm{e}}$ range. If our results are converted to $500 \mathrm{MW}_{\mathrm{e}}$ by using equation (2), the costs would be at the same level with other published results (Fi. 6) [37,41-43] at a level of US\$32-35/tonne $\mathrm{CO}_{2}$. This shows that the results from this study are reasonable.

- Cost of Avoided $\mathrm{CO}_{2}$, \$/tonne aElectricity Cost Increase, $\$ / \mathrm{MWh}$

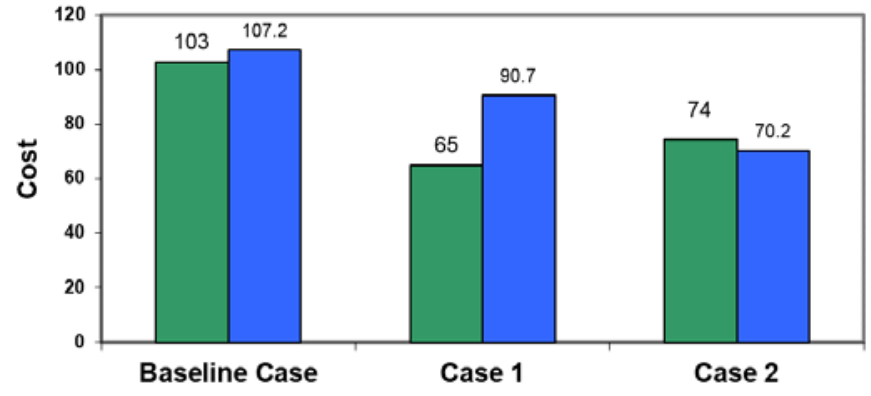

Figure 4. Costs of $\mathrm{CO}_{2}$ avoided and the electricity generation increment

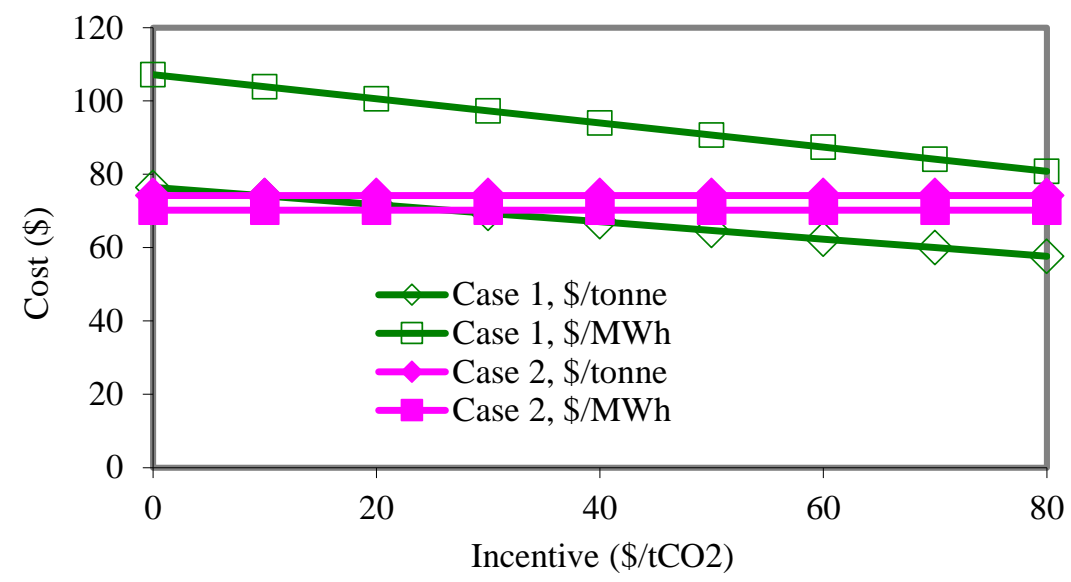

Figure 5. Costs of $\mathrm{CO}_{2}$ avoided and electricity generation increment versus $\mathrm{CO}_{2}$ incentive for Cases 1 and 2

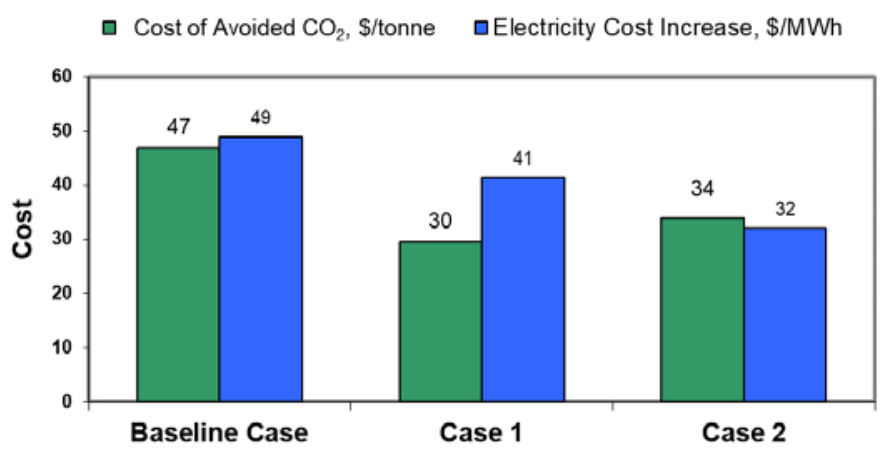

Figure 6. Costs of $\mathrm{CO}_{2}$ avoided and the electricity generation increment converted to $500 \mathrm{MW}_{\mathrm{e}}$ 


\section{Conclusion}

The impacts of the biomass cofiring are to reduce carbon capture cost of a power plant firing coal only to meet the same level of $\mathrm{CO}_{2}$ emission reduction. For low or high incentive scenarios, a power plant can select Case 1 or Case 2 accordingly.

Currently, the cost of $\mathrm{CO}_{2}$ avoided for coal power generation plants is still high because of the enormous equipment capital and operating/maintenance costs for all the three options in this study.

Two emerging factors have significant influence on the economics of carbon dioxide capture from electric power plants. First, government incentives for $\mathrm{CO}_{2}$ capture could offset part of the capture cost for coal and biomass cofiring cases. The cost of electricity of coal and biomass co-firing with $90 \% \mathrm{CO}_{2}$ avoided is $35 \%$ less than that of the coal-fired case at the same $\mathrm{CO}_{2}$ capture level with an assumed $\mathrm{CO}_{2}$ price of $\$ 50$ per tonne.

Second, the cost per tonne of $\mathrm{CO}_{2}$ avoided will drop dramatically if the biomass such as wood chips is co-fired with coal because of the neutral factor of biomass on $\mathrm{CO}_{2}$ emission, and the negative emissions realized in the cases studied (Figure 4).

The most significant research finding of this study is that Case 2 (co-firing with $60 \% \mathrm{CO}_{2}$ capture) has cost advantage over Case 1 (co-firing with $90 \% \mathrm{CO}_{2}$ capture) for electricity production. However, this cost advantage will diminish when the price of $\mathrm{CO}_{2}$ credit approaches $\$ 80$ per tonne.

The reason of Case 2's superiority over Case 1 is as follow: Case 2 requires less MEA than Case 1, which results in smaller equipment including the cooling tower, solvent pumps, and compressors. For example, the cooling tower operating cost is $32 \%$ lower in Case 2 than in Case 1 . In addition, the size and the suitable throughput of this equipment results in a lower de-rating factor for Case 2.

The de-rating rate drops to $18 \%$ for Case 2 from $26 \%$ for both Case 1 and the Base Case. The small de-rating factor of Case 2 is due to smaller heat duty of the re-boiler, as well as lower electricity power consumption by pumps and smaller compressor motors.

The study is based on some future governmental carbon incentive scenarios. It should be pointed out that there are uncertainties in the whole carbon capture and renewable technology development path in this study, as well as in the literatures. Further studies and development are necessary to lead to eventual implementation of biomass cofiring and carbon capture in power plants.

\section{Acknowledgements}

Part of this research has been funded by Natural Resources Canada through Clean Energy Program. Wei Jiang's contribution is gratefully acknowledged, who was a coop student from the Department of Mechanical Engineering, the University of Ottawa.

\section{References}

[1] IEA Annual Review, IEA Greenhouse Gas R\&D Program. 2010.

[2] Hock R, Rasul G, Adler C, Caceres B, Gruber S, Hirabayashi Y, Jackson M, Kääb A, Kang S, Kutuzov S, Milner A. High Mountain Areas: In: IPCC Special Report on the Ocean and Cryosphere in a Changing Climate, 2019.

[3] Technology Roadmap, Bioenergy for Heat and Power, IEA. 2012.

[4] Biennial Review Report, Biomass Program, DOE. 2011.

[5] Knapp S, Güldemund A, Weyand S, Schebek L. Evaluation of co-firing as a cost-effective short-term sustainable $\mathrm{CO}_{2}$ mitigation strategy in Germany. Energy, Sustainability and Society. 2019;9(1):32.

[6] Roni MS, Chowdhury S, Mamun S, Marufuzzaman M, Lein W, Johnson S. Biomass co-firing technology with policies, challenges, and opportunities: A global review. Renewable and Sustainable Energy Reviews. 2017;78:1089-1101.

[7] IEA “Good practice Guidelines”, Bioenergy Project Development \& Biomass Supply. 2007.

[8] Maciejewska AK, Veringa H, Sanders JP, Peteves SD. Co-firing of biomass with coal: constraints and role of biomass pretreatment. Office for Official Publications of the European Communities; 2006.

[9] Miller BG. Clean coal engineering technology. Elsevier; 2010.

[10] Zhuang Q, Clements B, Li Y. From ammonium bicarbonate fertilizer production process to power plant $\mathrm{CO}_{2}$ capture. International Journal of Greenhouse Gas Control. 2012;10:56-63.

[11] Verma M, Loha C, Sinha AN, Chatterjee PK. Drying of biomass for utilising in co-firing with coal and its impact on environment-A review. Renewable and Sustainable Energy Reviews. 2017;71:732-741.

[12] The World Bank Climate Finance Report. 2019.

[13] Biello D. Scientific American. 2011. 
[14] Kotchen MJ, Turk ZM, Leiserowitz AA. Public willingness to pay for a US carbon tax and preferences for spending the revenue. Environmental Research Letters. 2017;12(9):094012.

[15] Pretis F. Does a carbon tax reduce $\mathrm{CO}_{2}$ emissions? Evidence from British Columbia. Evidence From British Columbia (February 8, 2019). 2019 Feb 8.

[16] Metcalf G.-E. Paying for pollution: why a carbon tax is good for America. Oxford University Press; 2018.

[17] Doelle M. Toward a Principled Design of Carbon Pricing Systems: Lessons from Nova Scotia's Proposal to Meet the Carbon Pricing Requirement in the Pan-Canadian Framework for Climate Change. Journal of Environmental Law and Practice. 2018 Jul 1;31(3):293-309.

[18] Regulations Amending the Reduction of Carbon Dioxide Emissions from Coal-fired Generation of Electricity Regulations: SOR/2018-263, November 30, 2018

[19] http://www.roperld.com/science/minerals/shalegas.htm. (accessed August 2020)

[20] Ritchie H, Roser M. Fossil fuels. Our World in Data. 2017 Oct 2.

[21] Versteeg P, Advanced Amine and Ammonia Systems for Greenhouse Gas Control at Fossil Fuel Power Plants. [PhD Thesis]. Carnegie Mellon University. 2012.

[22] Peters M-S. Plant Design and Economics for Chemical Engineers. McGraw Hill, Toronto. 2003.

[23] Yi Q, Zhao Y, Huang Y, Wei G, Hao Y, Feng J, Mohamed U, Pourkashanian M, Nimmo W, Li W. Life cycle energy-economic- $\mathrm{CO}_{2}$ emissions evaluation of biomass/coal, with and without $\mathrm{CO}_{2}$ capture and storage, in a pulverized fuel combustion power plant in the United Kingdom. Applied energy. 2018 Sep 1;225:258-72.

[24] Abu-Zahra MR, Niederer JP, Feron PH, Versteeg GF. CO 2 capture from power plants: Part II. A parametric study of the economical performance based on mono-ethanolamine. International journal of greenhouse gas control. 2007 Apr 1;1(2):135-42.

[25] Biomass co-firing, A final Phase III Report, CCPC Technical Committee, November 2011.

[26] Co-firing of biomass with coal at the Dunedin Energy Centre, A Report by Energy for Industry, Revision 1, September 2008.

[27] Agbor E, Oyedun AO, Zhang X, Kumar A. Integrated techno-economic and environmental assessments of sixty scenarios for co-firing biomass with coal and natural gas. Applied Energy. 2016 May 1;169:433-49.

[28] Domenichini R, Gasparini F, Cotone P, Santos S. Techno-economic evaluation of biomass fired or co-fired power plants with post combustion $\mathrm{CO}_{2}$ capture. Energy Procedia. 2011 Jan 1;4:1851-60.

[29] Fluor Corporation Study Report. “Evaluation of Amine Scrubbing Options,” Canadian Clean Power Coalition, July 2003.

[30] Chemical Engineering Plant Cost Index. Chemical Engineering, p80, June 2017.

[31] Chemical Engineering Plant Cost Index. Chemical Engineering, p56, August 2013.

[32] Rubin ES, Davison JE, Herzog HJ. The cost of $\mathrm{CO}_{2}$ capture and storage. International Journal of Greenhouse Gas Control. 2015 Sep 1;40:378-400.

[33] Baltadjiev ND, Lettieri C, Spakovszky ZS. An investigation of real gas effects in supercritical $\mathrm{CO}_{2}$ centrifugal compressors. Journal of Turbomachinery. 2015 Sep 1;137(9).

[34] Patchigolla K, Oakey JE. Design overview of high pressure dense phase $\mathrm{CO}_{2}$ pipeline transport in flow mode. Energy Procedia. 2013 Jan 1;37:3123-30.

[35] ASHRAE Handbook 2017

[36] Chemical Market Reports 2017

[37] Ho MT. Techno-economic modelling of $\mathrm{CO}_{2}$ capture systems for Australian industrial sources. School of Chemical Sciences and Engineering, The University of New South Wales Sydney, Australia. 2007 Feb.

[38] Hirst D, Keep M. Carbon Price Floor (CPF) and the price support mechanism. House of Commons Library Briefing Paper. 2018 Jan 8(05927):20.

[39] G. Mason, Globe and Mail, January 12, 2018.

[40] P.-G. Rasmussen, Master Thesis, University of Massachusetts 2012.

[41] Jovanovic S. DOE Techno-Economic Analysis of 550 MWe subcritical PC power plant with $\mathrm{CO}_{2}$ capture. May 4, 2012.

[42] Mirfendereski Y. Master Thesis, "Techno-Economic Assessment of Carbon Capture and Sequestration Technologies in the Fossil Fuel-based Power Sector of the Global Energy-Economy System”, Technische Universität Berlin, May 2008.

[43] Ferrara G, Lanzini A, Leone P, Ho MT, Wiley DE. Exergetic and exergoeconomic analysis of postcombustion $\mathrm{CO}_{2}$ capture using MEA-solvent chemical absorption. Energy. 2017 Jul 1;130:113-28.

(C) 2020 by the author(s). This work is licensed under a Creative Commons Attribution 4.0 International License (http://creativecommons.org/licenses/by/4.0/). Authors retain copyright of their work, with first publication rights granted to Tech Reviews Ltd. 